\title{
Manufacturing Plant Location Selection in Logistics Network Using Analytic Hierarchy Process
}

\author{
Ping-Yu Chang ${ }^{1}$, Hsin-Yi Lin ${ }^{2}$ \\ ${ }^{1}$ Department of Industrial Engineering and Management, Ming Chi University of Technology, ${ }^{2}$ Cheng Uei Precision \\ Industry Co. Ltd., (Taiwan) \\ pchang@mail.mcut.edu.tw,.sylin929@gmail.com
}

Received: April 2015

Accepted: November 2015

\section{Abstract:}

Purpose: In recent years, numerous companies have moved their manufacturing plants to China to capitalize on lower cost and tax. Plant location has such an impact on cost, stocks, and logistics network but location selection in the company is usually based on subjective preference of high ranking managers. Such a decision-making process might result in selecting a location with a lower fixed cost but a higher operational cost. Therefore, this research adapts real data from an electronics company to develop a framework that incorporates both quantitative and qualitative factors for selecting new plant locations.

Design/methodology/approach: In-depth interviews were conducted with 12 high rank managers ( 7 of them are department manager, 2 of them are vice-president, 1 of them is senior engineer, and 2 of them are plant manager) in the departments of construction, finance, planning, production, and warehouse to determine the important factors. A questionnaire survey is then conducted for comparing factors which are analyzed using the Analytic Hierarchy Process (AHP).

Findings: Results show that the best location chosen by the developed framework coincides well with the company's primal production base. The results have been presented to the company's high ranking managers for realizing the accuracy of the framework. Positive 
responses of the managers indicate usefulness of implementing the proposed model into reality, which adds to the value of this research.

Practical implications: The proposed framework can save numerous time-consuming meetings called to compromise opinions and conflictions from different departments in location selection.

Originality/value: This paper adapts the Analytic Hierarchy Process (AHP) to incorporate quantitative and qualitative factors which are obtained through in-depth interviews with high rank managers in a company into the location decision.

Keywords: facility location, Analytic Hierarchy Process (AHP), supply chain management, delphi method, logistics network

\section{Introduction}

The increase in the number of orders and changes in supply chain have recently forced companies to expand or move their plants to various locations to improve their competitiveness. Plant locations have such an impact on cost and stocks that it should be thoroughly considered to strengthen the competitiveness of the company. Although the importance of location selection has been recognized in the literature, adjustment of academic findings seem necessary before implementing them into practical cases; This is because academic outcomes usually comprise mathematical modeling based on assumptions. Using mathematical models requires access to advanced solution techniques (such as metaheuristics) or computer equipment to obtain feasible locations in a reasonable time. In addition, mathematical modeling primarily deals with quantitative analysis without incorporating qualitative issues. Using only quantitative analysis will lead to choosing a location with the lowest real estate price or capital involved. Although merely focusing on cost and its minimization can positively affect the company's fiscal budget by lowering the initial cost, the impact from other factors is simply neglected. For example, a company in China can purchase the usage right of a land for maximum 50 years. China provinces usually waive land cost for companies that locate new plants to stimulate local economy. However, such a selection may result in higher transportation cost, poorer supplier network, and longer customer response time.

To incorporate qualitative factors in location selection, numerous time-consuming meetings are always called to compromise opinions and conflictions from different departments. For example, financial department prefers a location to reduce cost while the manufacturing and sales departments concentrate on the component supply network and on-time delivery, 
respectively. Such conflictions can thwart meetings, and the final decision is then determined by a high ranking manager such as the president or vice president. Such a decision will not take every factor into consideration and will usually result in a biased location choice. Hence, this research tries to propose a framework in determining facility location to avoid time consuming meetings for manufacturing industries with the adaption of the Analytic Hierarchy Process (AHP) to incorporate quantitative and qualitative factors into the decision. There are two objectives in the research. One is to obtain and to categorize main criteria from decision making managers so that future location decision can be made by reviewing these criteria. The second objective is to simplify the decision making process and reduce decision making time with the incorporation of AHP method. AHP was developed by Saaty in 1970 and is known to effectively coordinate the impact of different factors on the same basis. In this research, the procedures of AHP are discussed and implemented in a company to realize its usefulness for location selection. The structure of the research is as follows: Section 1 introduces the motivation and the objective of the research while Section 2 discusses the literature. Section 3 lists the procedures, and Section 4 presents the implementation of the procedures with real data. Sensitivity analysis is also presented in Section 4 and conclusions are made in Section 5.

\section{Literature Reviews}

Most previous literatures have been devoted to facility location using mathematical models. Randhawa and West (1995) showed that an incorrect location will affect the production rate due to low efficiency of the transportation system, resulting increased costs. Balinski (1965) developed a mathematical model called the Fixed Charge Location Problem (FCLP), which minimized the fixed cost and transportation cost when determining the optimal facility location. Huff (1966) demonstrated a gravity model to determine the optimal facility location considering competition from other companies and uncertainty of customer demand. Church and Revelle (1976) used average travel distance to efficiently find the best location and showed that an increase in average travel distance decreases the efficiency of the location.

Nozick and Turnquist (2001) provided a mathematical model to determine location for a distribution center considering inventory and transportation costs plus service level. They also showed that a good logistics system can locate the distribution center at its best location, which should consider fixed cost, inventory cost, and transportation cost. According to Nozick and Turnquist (2001), distance to customers and distribution centers are important parameters for a good logistics system of a convenient store. Furthermore, a mathematical model has been suggested to achieve the optimal convenient store location with maximum sales and minimum transportation cost. Hahn and Bunyaratavej (2010) conducted empirical research on the growing demand to offshore services to understand the impact of wages and personnel quality on firm choices of offshore locations. They empirically examined the service cultural 
alignment and investigated the impact of cultural dimensions on the location of offshore service projects. Their research showed that Western and Asian firms do not have different cultural preferences. McDermott and Stock (2011) analyzed 264,000 patients in cardiology wards of New York State to understand the hospital cost performance. They concluded that focus on one line of service in hospitals can lower costs. Handley and Benton Jr. (2013) conducted research in 102 outsourcing relationships to understand the impact of a task and location specific complexity on costs. They used the hierarchical regression to analyze results and found that the scale of service and the distance between the customer and provider will result in higher level of control and costs.

Marin (2011) balanced the maximum and minimum number of customers allocated to every plant in a discrete facility location problem by developing two mathematical formulations and applied a branch-and-cut algorithm to achieve the optimal solution. Both formulations were tested with different instances and the results showed that large size instances could be solved in a reasonable time frame. Canbolat and von Massow (2011) studied the location problem with random demand point to minimize the expected maximum rectilinear distance. Some properties and a simulation approach to solve complex 2D cases were presented in their research. The simulation approach achieved nearly optimal solutions for the linear case and could be considered for solving location selection problems. Lee and Lee (2012) investigated facility location problem considering customer restrictions and preferences. A mixed integer programming formulation and a heuristic solution procedure using Lagrangian relaxation were proposed in their research; indicating that the solution procedure can achieve feasible solutions in a reasonable computation time frame. Arabani and Farahani (2012) reviewed the literature of aspects and characteristics of dynamics of FLPs. Having provided a broad overview of their mathematical formulations, they drew the possible directions of future research. Gulpinar, Pachamanova and Canakoglu (2013) studied a stochastic facility location problem in which multiple capacitated facilities and a stock out probabilistic requirement are incorporated. They provided robust approximations and numerical experiments to demonstrate the performance of the formula. The results showed that robust strategies outperform non robust strategies in average total cost.

AHP is a structured technique for organizing and analyzing decisions with both quantitative and qualitative attributes. Although numerous studies have principally used AHP in solving different problems, few have addressed determining facility locations. Jaques and Morgan (2004) used the Analytical Hierarchy process in a specific telecommunications case study, and propose new strategies to manage high risk categories of stock. The results show that better product design, MRP systems, and suppliers control can provide advantages for incorporating market changes. Ounnar and Pujo (2005) proposed a self-organized logistical network to improve supplier relationships. Their results suggest quantifying an evaluation of each potential supplier who responds to a call for proposal from a customer, according to rules and criteria that are impartial and common to all. Gaudenzi and Borghesi (2006) adapted AHP to evaluate supply 
chain risks that meet the supply chain objectives. The results show that the most critical supply chain risks come from careful evaluations of impacts and a consideration of the cause-effect relationships. Dagdeviren, Yavuz and Kilinc (2009) used AHP and TOPSIS in weapon selection. They applied AHP in analyzing the structure of the weapon selection problem and to determine weights of the criteria. The TOPSIS method is then used for obtaining final ranking. A case study in their research has showed the usefulness and effectiveness of the proposed method. Chen and Wang (2010) demonstrated six elements with 20 critical factors using AHP to evaluate information service industry in developing international market. Typical commercial software companies are analyzed and the results showed that product competition is the most effective factor while distribution/channel is the least effective factor. Vidal, Sabin, Martelli, Berhoune and Bonan (2010) applied AHP in selecting anti-cancer drugs within the pharmacy department of a hospital. The proposed method has been applied to the pharmaceutical chemotherapy compounding unit of a hospital in Paris. The weightings in the AHP model are used to identify drugs production on a make-to-stock basis. The results showed that AHP can be extended its usefulness in the health care management. Amiri (2010) used AHP to evaluate and select oil-fields development project. He applied AHP to achieve weights of the criteria and then used fuzzy TOPSIS method to obtain final ranking. The proposed method was applied in an example which demonstrated the usefulness and effectiveness of implementing AHP in decision making.

Ishizaka and Labib (2011) reviewed the main developments in AHP since its inception. Problem modelling, pair-wise comparisons, judgment scales, derivation methods, consistency indices, incomplete matrix, synthesis of the weights, sensitivity analysis, and group decisions are discussed in their research. Vidal, Marie and Bocquet (2011) propose a multi-criteria approach to project complexity evaluation. They conduct AHP on a case study within a start-up firm in the entertainment industry (musicals production). Their concluded that AHP is reliable, user friendly, global independent, and able to highlight project complexity sources. Hong and Xiaohua (2011) performed a study on location selection of multiple objectives by analyzing the construction process of AHP and identifying important factors for location selection of emergency logistics centers. An optimal solution with a feasible solution time frame was achieved. Rad, Naderi and Soltani (2011) considered the problem of clustering and ranking university majors in Iran. The evaluated 177 university majors with eight different criteria using AHP. Their results showed that Management, Mechanical and Information Technology Engineering are three top majors, based on view of the decision makers. After these three majors, engineering majors, such as Industrial and Civil Engineering along with Medicine, Film and Video Production and Law are more influential majors.

Tzeng, Teng, Chen and Opricovic (2002) applied AHP with five aspects and 11 criteria to develop a location evaluation hierarchy for a restaurant. Two possible alternatives, a commercial center and a new city administrative center, are to be proposed to the decision maker. Kuo, Chi and Kao (2002) used AHP to select the best location of the convenient store 
and neural network to understand the store performance. The results showed that proposed system is able to provide more accurate result than regression model in accuracy. Partovi (2006) presented a strategic decision making process to facility location problem which incorporates external and internal criteria. A case study was applied to demonstrate the usefulness of the proposed framework. Vahidnia, Alesheikh and Alimohammadi (2009) combined Geographical Information System (GIS) with fuzzy AHP to determine the optimal hospital site in an urban area. The result showed that selected optimal site covers more than 6.5 percent of population than other feasible sites. Choudhary and Shankar (2012) proposed an STEEP-fuzzy AHP based framework for evaluation and selection of optimal locations for thermal power plant. They also concluded that AHP is an appropriate method in location selection other than traditional way of decision making or by political interests. Sánchez-Lozano, García-Cascales and Lamata (2015) determined the best location of a solar thermoelectric power plant using AHP. Their result showed that AHP can deal with quantitative and qualitative criteria in selecting best location. The results validated the quality of the solution obtained by the proposed methodology, since for the 33 best alternatives obtained by AHP and ELECTRE-TRI there are 21 coincident alternatives.

Facility location has a well-developed theoretical background with a variety of models, methodologies, and solution techniques. These models addressed facility locations based on cost and operational analysis which will select location near low cost and high resource area without taking holistic and systematic approach. In addition, facility location selection based on operational analysis will determine the best location entirely from a company's manufacturing perspective without considering other critical activities of the organization. Therefore, this research adapts AHP method to incorporate both quantitative and qualitative criteria in location analysis.

Zhang, Deng, Wei and Deng (2012) developed a model based on AHP to evaluate E-Commerce security. The weights of the criteria are then combined using Dempster-Shafer theory to realize the evidences and to derive a decision for the degree of E-Commerce security. An example is provided in their research and efficiency of the model is illustrated. Lee, Kim, Kim and Oh (2012) investigate the important intangible priority factors for the transfer of technology through AHP method and correlation analysis. Their results indicate that prioritized factors are in the order of business feasibility (profitability), technological validity, technology licensing office capabilities. The most important criterion is business feasibility and the most important sub-factor for business feasibility is commercialization indicating that productivity, profitability, marketing and working capital funds are critical in buying new technologies.

AHP method has been extended with fuzzy logic and TOPSIS in many research. Farahani, SteadieSeifi and Asgari (2010) reviewed the literatures of multicriteria location problems in three categories including biobjective, multiobjective, and multiattribute problems and their solution methods. Jung (2011) proposed a fuzzy AHP-goal programming (GP) approach to 
integrate production-planning with manufacturing partners selection. Fuzzy AHP is applied to determine relative weights of manufacturing partners while GP is used to formulate the integrated production-planning problem. Ho, He, Lee and Emourznejad (2012) developed an integrated quality function deployment (QFD), fuzzy set theory, and AHP to determine the optimal third-party logistics (3PL) service providers. The developed method has been applied to Hong Kong-based enterprises and has outperformed other current approaches. Büyüközkan, Çifçi and Güleryüz (2011) used the SERVQUAL to examine factors of service quality and evaluated the identified factors using a fuzzy AHP. They implemented the proposed framework into a healthcare system to prove its usefulness. Calabrese, Costa and Menichini (2013) proposed a model integrating fuzzy logic and AHP to evaluate Intellectual Capital (IC) management and then applied it to the companies operating in the ICT service industry to realize the usefulness of the methodology. Although fuzzy logic and TOPSIS have been proved their usefulness in multicriteria analysis, this research only adapts AHP in location selection.

\section{Methodology}

Plant location is normally decided by high ranking managers in the industry. Numerous meetings have been called but cost and supplier network are the only parameters considered in such time-consuming meetings. Although the importance of a supplier network is recognized in the decision-making process, cost reduction rules out the first priority for industries. Therefore, the location with the minimum initial cost is usually selected. On the other hand, intelligent algorithm and simulation tool can be developed and are for sure to achieve optimal solution for location problems. However, these models and algorithms address facility locations based on quantitative indexes which will determine the best location from company's manufacturing or fiscal perspective without considering other critical activities. In addition, using only quantitative analysis will lead to choosing a location with the lowest real estate price or capital involved. Although merely focusing on cost and its minimization can positively affect the company's fiscal budget by lowering the initial cost, the impact from other factors is simply neglected (Partovi, 2006; Tzeng et al., 2002; Kuo et al., 2002; Vahidnia, et al., 2009; Choudhary \& Shankar, 2012; Sánchez-Lozano et al., 2015).

Also, this research tries to propose a location selection method which can easily be implemented in practical and easily be adjusted to environmental changes. Constructing a mathematical model for intelligent algorithm or a simulation model might require experts and time to transform practical concerns into equations and rules under assumptions. It will also impose need for time to adjust the models if the constraints or concerns in location selection have changed. Therefore, this research adapts the Delphi method to identify the important factors in location selection and uses AHP to determine the location. AHP is a measurement theory that prioritizes the hierarchy and consistency of judgmental data provided by a group of 
decision makers (Wu, Lin \& Chen, 2007). It includes every decision makers' evaluation using pair-wise comparisons of factors for alternatives. Four steps are required for AHP analysis. Step 1 is to define the overall goals and step 2 is to construct AHP hierarchy based on the criteria and subcriteria where, at least, three tiers including overall goals, criteria, and alternatives should be constructed. Subcriteria can be inserted between criteria and alternatives for more precise evaluation. Step 3 is to construct the pair-wise comparison matrix A between factors and alternatives in each tier while step 4 checks the consistency of the questionnaires and determines the best strategy based on the calculated weights.

Saaty (1980) suggested use of nine evaluation scales marked at 1, 3, 5, 7, and 9 as "equally important", "slightly more important", "strongly more important", "demonstrably more important" and "absolutely more important", respectively, for designing the questionnaire. Matrix $A$ is an $n \times n$ matrix where $n$ denotes the number of criteria to be compared. Equation (1) shows the parameters within matrix $A, a_{i j}$ represents the result between the $i^{\text {th }}$ criteria in rows and the $j^{\text {th }}$ criteria in columns and is equal to $1 / a_{j i}$. For matrix $\mathrm{A}$, to maintain the consistency, the relation between weight of $i^{\text {th }}$ criteria $\left(w_{i}\right)$ and $a_{i j}$ will be equal to $w_{i} / w_{j}$, for all $i$ and $j$. Also, this research uses column vector average shown in equation (2) to approximately calculate $w_{i}$.

$$
\begin{aligned}
& A=\left[a_{i j}\right\rceil=\left[\begin{array}{cccc}
1 & a_{12} & \cdots & a_{1 n} \\
1 / a_{12} & 1 & \cdots & a_{2 n} \\
\vdots & \vdots & \ddots & \vdots \\
1 / a_{1 n} & 1 / a_{1 n} & \cdots & 1
\end{array}\right]=\left[\begin{array}{cccc}
w_{1} / w_{1} & w_{1} / w_{2} & \cdots & w_{1} / w_{n}{ }^{-} \\
w_{2} / w_{1} & w_{2} / w_{2} & \cdots & w_{2} / w_{n} \\
\vdots & \vdots & \ddots & \vdots \\
w_{n} / w_{1} & w_{n} / w_{2} & \cdots & w_{n} / w_{n}
\end{array}\right. \\
& w_{i}=\frac{1}{n} \sum_{j}^{n} \frac{a_{i j}}{\sum_{i=1}^{n} a_{i j}} \quad i, j=1,2, \cdots, n \text {. }
\end{aligned}
$$

To test the consistency of matrix $A$, Saaty (1990) suggested using eigenvalue $\lambda_{\max }$ within equation (3) for calculating eigenvector $X$. The calculation of eigenvalue $\lambda_{\max }$ is demonstrated in equation (4).

$$
\begin{aligned}
& \left(A-\lambda_{\max } I\right) X=0 \\
& \lambda_{\max }=\sum_{j=1}^{n} a_{i j} \frac{w_{j}}{w_{i}} .
\end{aligned}
$$

The eigenvalue $\lambda_{\max }$ is then applied to achieve Consistency Index (CI) and Consistency Ration (CR) to confirm the consistency of matrix $A$, where C.I. $=\frac{\lambda_{\max }-n}{n-1}$ and $\mathrm{CR}=\frac{\mathrm{CI}}{\mathrm{RI}}$. 
RI is Random Index value developed by Oak Ridge National laboratory and Warton School for the consistency test. Table 1 demonstrates the value of RI in different numbers of criteria $(n)$. If $\mathrm{CI}$ and CR are less than 0.1 , consistency is sustained for the questionaire.

\begin{tabular}{|c|c|c|c|c|c|c|c|c|c|c|c|c|c|c|c|}
\hline $\mathbf{n}$ & $\mathbf{1}$ & $\mathbf{2}$ & $\mathbf{3}$ & $\mathbf{4}$ & $\mathbf{5}$ & $\mathbf{6}$ & $\mathbf{7}$ & $\mathbf{8}$ & $\mathbf{9}$ & $\mathbf{1 0}$ & $\mathbf{1 1}$ & 12 & 13 & 14 & 15 \\
\hline R.I. & 0.0 & 0.0 & 0.58 & 0.9 & 1.12 & 1.24 & 1.32 & 1.41 & 1.45 & 1.49 & 1.51 & 1.48 & 1.56 & 1.57 & 1.58 \\
\hline
\end{tabular}

Table 1. Random Index value

\section{Case Study}

The company under study was founded in 1986 and concentrated on 3C (Communication, Consumable, and Computer) components and power supply manufacturing. Their customers included Microsoft, Apple, Hewlett-Packard (HP), Acer, Alpha, Motorola, Sony, NEC, Siemens, Nokia, Sanyo, and Panasonic. Its manufacturing plants are located mainly in China and sales points cover countries in Asia, America, and Europe. The company tries to determine a new plant location among three preferred locations TG, KS, and TJ.

To identify the important factors of locations, in-depth interviews were conducted with 12 high rank managers ( 7 of them are department manager, 2 of them are vice-president, 1 of them is senior engineer, and 2 of them are plant manager) in the departments of construction, finance, planning, production, and warehouse. Each interview lasts at least 30 minutes with questions of their experiences in location selections, factors considered in location selection, subcriteria of the factors, and rate the importance of the factors. Managers have at least nine-year experience in location selection and they provided important factors based on location selection experiences and current operation problems due to location selections. During the interviews, managers in finance express concerns in Cost while managers in planning and production have concerns in Workforce, Supply Chain, Customs, and Performance Index. Managers in construction think Cost and Environmental issues are important factors while managers in warehouse express concerns in Supply Chain, Customs, and Performance Index. These interviews were then summarized into six factors and three levels for each factor. The six factors are Cost, Workforces, Supply chain, Environmental issues, Customs, and Performance index that are discussed as follows:

1. Cost: Cost is always the most important factor in building a new plant. Three subcriteria have been identified.

a) Land purchasing cost: Land purchasing cost is usually the largest portion in the fiscal budget for building a new plant. In China, the rapidly growing economy has increased the land price, which resulted in rise in land purchasing cost. 
b) Construction cost: Two types of building construction, steel structure and reinforced concrete factory plant, are usually adapted in manufacturing industries. Construction of steel structure factory plant is restrained to one floor in a larger area and takes six months. A reinforced concrete factory plant, however, can be constructed in multiple stories in a smaller land and takes, at least, one and a half years.

c) Rental opportunities: In China, some provinces have empty plants and employee residential buildings for rental, which will reduce cost and time for the new plant to be ready for production.

2. Workforces: In 2010, the development of western China and higher wages allured workers to move from coastal cities to these areas that resulted in workforce shortage in coastal cities. Hence, workforce is an important factor in plant location selection.

a) Labor force population: Although China is a country with 1.5 billion people; local workforces are usually not enough to support the demand of the enterprises. A large chunk of workforces come from interior cities with the aim of higher wages. Such workforces will immediately leave their positions if higher wages are offered by other companies or areas, causing high personnel turnover rate.

b) Minimum wages: In China, cities have various minimum wages. Choosing the lowest wage will reduce the personnel cost of a company.

c) Social insurance: In China, different governments will legislate different regulations of social insurance requirements and coverage amounts. For example, provinces in Southern China usually encounter lower social insurance requirements and coverage amounts compared to Northern and Eastern China.

3. Supply chain: Logistics cost and time have always been important issues of a company to enhance its competitiveness. To reduce logistics cost and time, a plant should be located within an appropriate supply chain network so that suppliers and manufacturers can provide components and finished product to the manufacturers and the customers on time.

a) Supplier network: Pursuing zero inventory to reduce cost is always an important strategy for electronic manufacturing industries and on-time delivery from suppliers is the key factor to reach this goal.

b) Logistics: Companies usually use bonded logistics parks to accelerate logistics process. They comprise warehouse distribution centers and transportation, making 
them able to store taxed merchandise. Logistics parks are approved by the customs office to have the same authority of import and export customs.

c) Ports: The distance from plant location to the ports has an impact on the transportation and lead time. Usually, a location closer to the port or airport will have higher priority in location selection.

4. Environmental issues: Environmental regulations have become stricter especially on the waste disposals by electronic industries. Three subcriteria are identified for environmental issues.

a) Sewage system: Some electronic manufacturing processes require electroplating that will dispose of highly polluted waste water. The waste water can only be purified using special sewage system. Hence, a location with a ready special sewage system will have higher priority in location selection.

b) Electroplating certification: Most Chinese provinces have declined application to electroplating certification due to its high pollution. Manufacturing process is not allowed to be operated without electroplating certification. Hence, the convenience of obtaining electroplating certification is an important factor in location selection.

c) Regulation: Different Chinese provinces have different regulations and levels of cooperation in term of environment inspection; thus, certifications are also different among governments.

5. Customs: Manufacturing plants are normally operational 24 hours a day and therefore, final goods are exported at any time of day to fulfill orders. Hence, a customs office that can cooperate with companies at any specific time will have higher priority in location selection.

a) Levels of customs: There are two levels of customs in China. Level A customs can extend its service time to help companies while level B customs area will operate only during office hours.

b) Bonded area: Logistics parks, bonded warehouses, and export processing zones are the three types of special bonded areas.

c) Effectiveness: The capability of a customs office to cooperate with early import/export processing, emergency, rapid import/export processing, and door-todoor examination are considered as important factors. 
6. Performance index: The objective of a new plant is to fulfill customers' requirements so that customer satisfaction can be increased. Three subcriteria of responsive time, order quantities, and on-time delivery are identified in this criterion.

a) Responsive time: It is defined as the time taken to respond and complete customer requirements, such as orders and product specification adjustments. The shorter the time, the higher the customer satisfaction.

b) Order quantities: A new plant should provide enough capacity for customer demand.

c) On-time delivery: Delivering orders on-time is an import factor to improve customer satisfaction.

Figure 1 demonstrates the structure of criteria and subcriteria. The overall goal is to select an optimal location. Six criteria with three subcriteria for each criterion are identified for AHP analysis. Three alternatives, TG, KS, and TJ are also identified in the structure. Pair-wise comparison against the criteria, subcriteria, and alternatives will have to be conducted for decision analysis. To compensate the variation of subjective evaluation on pair-wise comparison, direct interview is adapted for AHP questionnaires on 30 employees (12 high rank managers are included) with experiences ranged from 5 to 26 years. The jobs of the employees are plant managers, department managers, consultants, engineers, vice presidents and production planners from finance, production planning, and warehouse departments. The results and consistency of pair-wise comparison are demonstrated in the next section. 


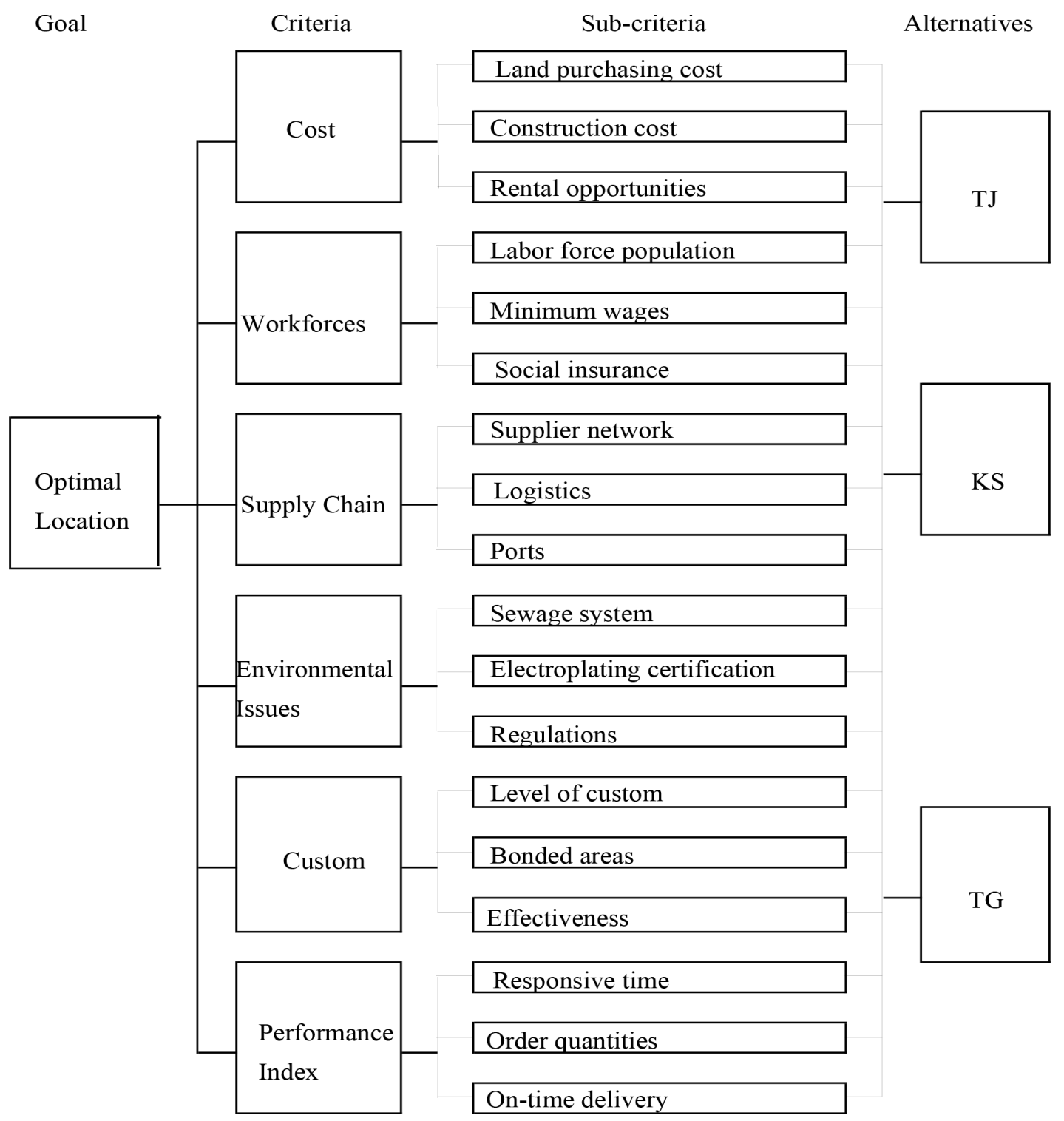

Figure 1. Structure of criteria

\subsection{Pair-wise Comparison Matrix}

Table 2 shows the pair-wise comparison matrix of the six criteria in the second tier.

\begin{tabular}{|c|r|r|r|r|r|r|r|}
\hline Criteria & Cost & $\begin{array}{c}\text { Supply } \\
\text { Chain }\end{array}$ & Workforces & $\begin{array}{c}\text { Environmental } \\
\text { issues }\end{array}$ & Customs & $\begin{array}{c}\text { Performance } \\
\text { index }\end{array}$ & Weight \\
\hline Cost & 1.0 & 3.0 & 2.0 & 5.0 & 7.0 & 1.0 & 0.287 \\
\hline Supply chain & 0.3 & 1.0 & 0.3 & 5.0 & 5.0 & 0.3 & 0.127 \\
\hline Workforces & 0.5 & 3.0 & 1.0 & 5.0 & 7.0 & 0.3 & 0.197 \\
\hline $\begin{array}{c}\text { Environmental } \\
\text { issues }\end{array}$ & 0.2 & 0.2 & 0.2 & 1.0 & 3.0 & 0.2 & 0.055 \\
\hline Customs & 0.1 & 0.2 & 0.1 & 0.3 & 1.0 & 0.2 & 0.034 \\
\hline Performance index & 1.0 & 3.0 & 3.0 & 5.0 & 5.0 & 1.0 & 0.300
\end{tabular}

Table 2. Pair-wise comparison matrix of criteria 
Accordingly, $\lambda$ value is 6.447 and the RI value is 1.24 . Hence, CI and CR value are 0.09 and 0.072 , respectively. The CR value is less than 0.1 , which indicates consistency in the questionnaire results. The weights of the criteria are also shown in Table 2. The cost and performance index are in charge of $58.7 \%$ of the weights while the environmental issues and customs make less than $10 \%$ of the weights. Therefore, cost and performance index are the two most important factors in location decision.

\begin{tabular}{|c|c|c|c|c|}
\hline Cost & $\begin{array}{l}\text { Land purchasing } \\
\text { cost }\end{array}$ & Construction cost & $\begin{array}{c}\text { Rental } \\
\text { opportunities }\end{array}$ & Weight \\
\hline Land purchasing cost & 1.000 & 3.000 & 5.000 & 0.633 \\
\hline Construction cost & 0.333 & 1.000 & 3.000 & 0.260 \\
\hline Rental opportunities & 0.200 & 0.333 & 1.000 & 0.107 \\
\hline \multicolumn{5}{|c|}{$\lambda=3.0387 ; \mathrm{RI}=0.58 ; \mathrm{CI}=0.0194 ; \mathrm{CR}=0.0334$} \\
\hline Supply chain & Suppliers network & Logistics & Ports & Weight \\
\hline Suppliers network & 1.0000 & 3.0000 & 7.0000 & 0.6278 \\
\hline Logistics & 0.3330 & 1.0000 & 7.0000 & 0.3129 \\
\hline Ports & 0.1111 & 0.1429 & 1.0000 & 0.0594 \\
\hline \multicolumn{5}{|c|}{$\lambda=3.0271 ; \mathrm{RI}=0.58 ; \mathrm{CI}=0.0136 ; \mathrm{CR}=0.0234$} \\
\hline Workforces & Minimum wages & Labor force population & Social insurance & Weight \\
\hline Minimum wages & 1.0000 & 3.0000 & 5.0000 & 0.6334 \\
\hline Labor force population & 0.3330 & 1.0000 & 3.0000 & 0.2604 \\
\hline Social insurance & 0.2000 & 0.3333 & 1.0000 & 0.1062 \\
\hline \multicolumn{5}{|c|}{$\lambda=3.0384 ; \mathrm{RI}=0.58 ; \mathrm{CI}=0.0192 ; \mathrm{CR}=0.0331$} \\
\hline Environmental issues & Sewage system & $\begin{array}{l}\text { Electroplating } \\
\text { certification }\end{array}$ & Regulations & Weight \\
\hline Sewage system & 1.0000 & 0.2000 & 0.1429 & 0.0738 \\
\hline Electroplating certification & 5.0000 & 1.0000 & 0.3333 & 0.2828 \\
\hline Regulations & 7.0000 & 3.0000 & 1.0000 & 0.6434 \\
\hline \multicolumn{5}{|c|}{$\lambda=3.0655 ; \mathrm{RI}=0.58 ; \mathrm{CI}=0.0328 ; \mathrm{CR}=0.0565$} \\
\hline Customs & Level of customs & Bonded areas & Effectiveness & Weight \\
\hline Level of customs & 1.0000 & 3.0000 & 7.0000 & 0.6434 \\
\hline Bonded areas & 0.3333 & 1.0000 & 5.0000 & 0.2828 \\
\hline Effectiveness & 0.1429 & 0.2000 & 1.0000 & 0.0738 \\
\hline \multicolumn{5}{|c|}{$\lambda=3.0655 ; R I=0.58 ; C I=0.0328 ; C R=0.0565$} \\
\hline Performance index & Responsive time & Order quantities & On-time delivery & Weight \\
\hline Responsive time & 1.0000 & 0.2000 & 0.3333 & 0.1062 \\
\hline Order quantities & 5.0000 & 1.0000 & 3.0000 & 0.6333 \\
\hline On-time delivery & 3.0000 & 0.3333 & 1.0000 & 0.2605 \\
\hline
\end{tabular}

Table 3. Pair-wise comparison matrix of subcriteria

Table 3 demonstrates the results of pair-wise comparison matrix of subcriteria. All CR values are less than 0.1 , which indicate the consistency of the subcriteria. In each criterion, the weight of a specific subcriterion dominates the rest of the weights. For instance, land purchasing cost encounters a weight of 0.633 in cost while other two subcriteria, construction cost and rental opportunities, only weigh 0.26 and 0.107 , respectively. Moreover, supplier 
network, minimum wages, regulations, level of customs, and order quantities also dominate other two subcriteria in supply chain, workforce, environmental issues, customs and performance index, respectively.

\begin{tabular}{|c|c|c|c|c|}
\hline \multirow{2}{*}{ Criterion (weight) } & \multicolumn{2}{|c|}{ Subcriteria and weights } & \multirow{2}{*}{$\begin{array}{l}\text { Total weight of } \\
\text { subcriteria }\end{array}$} & \multirow{2}{*}{ Rank } \\
\hline & Subcriteria & Weight & & \\
\hline \multirow{3}{*}{ Cost $(0.287)$} & Land purchasing cost & 0.6333 & 0.1816 & 2 \\
\hline & Construction cost & 0.2605 & 0.0747 & 6 \\
\hline & Rental opportunities & 0.1062 & 0.0304 & \\
\hline \multirow{3}{*}{$\begin{array}{l}\text { Supply Chain } \\
(0.127)\end{array}$} & Supplier network & 0.6278 & 0.0799 & 4 \\
\hline & Logistics & 0.3129 & 0.0398 & 8 \\
\hline & Ports & 0.0594 & 0.0076 & \\
\hline \multirow{3}{*}{ Workforces (0.197) } & Minimum wages & 0.6334 & 0.1246 & 3 \\
\hline & Labor force population & 0.2604 & 0.0512 & 7 \\
\hline & Social insurance & 0.1062 & 0.0209 & \\
\hline \multirow{3}{*}{$\begin{array}{l}\text { Environmental issues } \\
\qquad(0.055)\end{array}$} & Sewage system & 0.0738 & 0.0041 & \\
\hline & Electroplating certification & 0.2828 & 0.0157 & \\
\hline & Regulations & 0.6434 & 0.0357 & 9 \\
\hline \multirow{3}{*}{ Customs (0.034) } & Level of customs & 0.6434 & 0.0218 & \\
\hline & Bonded areas & 0.2828 & 0.0096 & \\
\hline & Effectiveness & 0.0738 & 0.0025 & \\
\hline \multirow{3}{*}{$\begin{array}{l}\text { Performance index } \\
\qquad(0.3)\end{array}$} & Responsive time & 0.1062 & 0.0318 & 10 \\
\hline & Order quantities & 0.6333 & 0.1899 & 1 \\
\hline & On-time delivery & 0.2605 & 0.0781 & 5 \\
\hline
\end{tabular}

Table 4. The ranking of the subcriteria

Table 4 shows the results of ranking the subcriteria. Order quantities in the performance index criterion have the highest weight among other subcriteria. The weights of all three subcriteria in the performance index criterion are ranked in the top ten and two subcriteria (order quantities and on-time delivery) are also ranked in the top five. The subcriterion with the second highest weight is land purchasing cost while the third and fourth highest weights are minimum wages and logistics in workforce and supply chain, respectively.

Table 5 shows the pair-wise comparison results among alternatives for the subcriteria under cost, workforces, and supply chain. In Table 5, results related to land purchasing cost, construction cost and rental opportunities are listed. CR values for these three subcriteria are less than 0.1 , which indicate the consistency of the results. Furthermore, TG outperforms the other two alternatives in construction cost and rental opportunities while KS outperforms the other two alternatives in land purchasing cost. For the subcriteria under workforces, the results of labor force population, minimum wages, and Social insurance are also presented in Table 5. CR values for these three subcriteria are less than 0.1 , which indicate the consistency of the 
results. Also, TG outperforms the other two alternatives in all three subcriteria. For the subcriteria under supply chain, the results of suppliers network, logistics and ports are presented. CR values for these three subcriteria are less than 0.1 , which indicate the consistency of the results. Also, TG outperforms the other two alternatives in all three subcriteria.

\begin{tabular}{|c|c|c|c|c|c|}
\hline \multicolumn{6}{|c|}{ Cost } \\
\hline Land purchasing cost & TG & KS & TJ & Weight & \multirow{4}{*}{$\begin{aligned} \lambda=3.0658 ; & R I=0.58 \\
C I & =0.0329 ; C R\end{aligned}$} \\
\hline TG & 1 & 0.1429 & 0.3333 & 0.0833 & \\
\hline KS & 7 & 1 & 5 & 0.7235 & \\
\hline TJ & 3 & 0.2 & 1 & 0.1932 & \\
\hline Construction cost & TG & KS & TJ & Weight & \multirow{4}{*}{$\begin{aligned} \lambda & =3.0539 ; \mathrm{RI}=0.58 \\
\mathrm{CI} & =0.027 ; \mathrm{CR}=0.0465\end{aligned}$} \\
\hline TG & 1 & 3 & 3 & 0.5889 & \\
\hline KS & 0.3333 & 1 & 2 & 0.2519 & \\
\hline T] & 0.3333 & 0.5 & 1 & 0.1593 & \\
\hline Rental opportunities & TG & KS & TJ & Weight & \multirow{4}{*}{$\begin{aligned} \lambda=3.0037 ; & R I=0.58 \\
C I & =0.0018 ; C R\end{aligned}$} \\
\hline TG & 1 & 5 & 3 & 0.6479 & \\
\hline KS & 0.2 & 1 & 0.5 & 0.1222 & \\
\hline TJ & 0.333 & 2 & 1 & 0.2299 & \\
\hline \multicolumn{6}{|c|}{ Workforces } \\
\hline Labor force population & TG & KS & TJ & Weight & \multirow{4}{*}{$\begin{aligned} \lambda=3.0092 ; & R I=0.58 \\
C I & =0.0046 ; C R\end{aligned}$} \\
\hline TG & 1 & 3 & 2 & 0.539 & \\
\hline KS & 0.3333 & 1 & 0.5 & 0.1638 & \\
\hline TJ & 0.5 & 2 & 1 & 0.2973 & \\
\hline Minimum wage & TG & KS & TJ & Weight & \multirow{4}{*}{$\begin{aligned} \lambda=3.0092 ; & R I=0.58 \\
C I & =0.0046 ; C R\end{aligned}$} \\
\hline TG & 1 & 2 & 3 & 0.539 & \\
\hline KS & 0.5 & 1 & 2 & 0.2973 & \\
\hline T] & 0.3333 & 0.5 & 1 & 0.1638 & \\
\hline Social insurance & TG & KS & T了 & Weight & \multirow{4}{*}{$\begin{array}{l}\lambda=3.0539 ; \quad R I=0.58 \\
C I=0.027 ; C R=0465\end{array}$} \\
\hline TG & 1 & 3 & 3 & 0.5889 & \\
\hline KS & 0.3333 & 1 & 2 & 0.2519 & \\
\hline $\mathrm{T}]$ & 0.3333 & 0.5 & 1 & 0.1593 & \\
\hline \multicolumn{6}{|c|}{ Supply Chain } \\
\hline Supplier network & TG & KS & $\mathrm{TJ}$ & Weight & \multirow{4}{*}{ 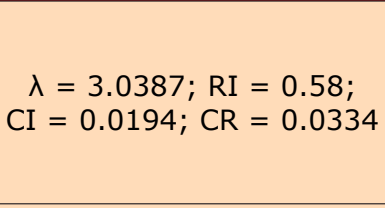 } \\
\hline TG & 1 & 3 & 5 & 0.6333 & \\
\hline KS & 0.3333 & 1 & 3 & 0.2605 & \\
\hline $\mathrm{TJ}$ & 0.2 & 0.3333 & 1 & 0.1062 & \\
\hline Logistics & TG & KS & TJ & Weight & \multirow{4}{*}{$\begin{aligned} \lambda=3.0537 ; & R I=0.58 \\
C I=0.0269 ; C R & =0.0463\end{aligned}$} \\
\hline TG & 1 & 2 & 2 & 0.4905 & \\
\hline KS & 0.5 & 1 & 2 & 0.3119 & \\
\hline T] & 0.5 & 0.5 & 1 & 0.1976 & \\
\hline Ports & TG & KS & TJ & Weight & \multirow{4}{*}{$\begin{aligned} \lambda=3.0092 ; & R I=0.58 \\
C I=0.0046 ; & C R=0.0079\end{aligned}$} \\
\hline TG & 1 & 2 & 3 & 0.539 & \\
\hline KS & 0.5 & 1 & 2 & 0.2973 & \\
\hline TJ & 0.3333 & 0.5 & 1 & 0.1638 & \\
\hline
\end{tabular}

Table 5. Pair-wise comparison matrix among alternatives for subcriteria under cost, workforces, and supply chain 


\begin{tabular}{|c|c|c|c|c|c|}
\hline \multicolumn{6}{|c|}{ Environmental Issue } \\
\hline Sewage system & TG & KS & TJ & Weight & \multirow{4}{*}{$\begin{aligned} \lambda=3.0092 ; & R I=0.58 \\
C I=0.0046 ; & C R=0.0079\end{aligned}$} \\
\hline TG & 1 & 2 & 3 & 0.539 & \\
\hline KS & 0.5 & 1 & 2 & 0.2973 & \\
\hline TJ & 0.3333 & 0.5 & 1 & 0.1638 & \\
\hline Electroplating certification & TG & KS & TJ & Weight & \multirow{4}{*}{$\begin{aligned} \lambda=3.0537 ; & R I=0.58 \\
C I=0.0268 ; & C R=0.0463\end{aligned}$} \\
\hline TG & 1 & 1 & 0.5 & 0.2611 & \\
\hline KS & 1 & 1 & 1 & 0.3278 & \\
\hline TJ & 2 & 1 & 1 & 0.4111 & \\
\hline Regulations & TG & KS & TJ & Weight & \multirow{4}{*}{$\begin{aligned} \lambda=3.0537 ; & R I=0.58 \\
C I & =0.0269 ; C R\end{aligned}$} \\
\hline TG & 1 & 2 & 2 & 0.4905 & \\
\hline KS & 0.5 & 1 & 0.5 & 0.1976 & \\
\hline 0.5 & 0.5 & 2 & 1 & 0.3119 & \\
\hline \multicolumn{6}{|c|}{ Customs } \\
\hline Level of customs & TG & KS & TJ & Weight & \multirow{4}{*}{ 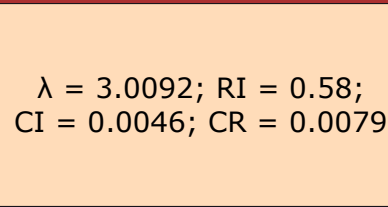 } \\
\hline TG & 1 & 2 & 3 & 0.539 & \\
\hline KS & 0.5 & 1 & 2 & 0.2973 & \\
\hline TJ & 0.3333 & 0.5 & 1 & 0.1638 & \\
\hline Function & TG & KS & TJ & Weight & \multirow{4}{*}{$\begin{array}{c}\lambda=3.0537 ; \mathrm{RI}=0.58 \\
\mathrm{CI}=0.0269 ; \mathrm{CR}=0.0463\end{array}$} \\
\hline TG & 1 & 2 & 2 & 0.4905 & \\
\hline KS & 0.5 & 1 & 2 & 0.3119 & \\
\hline TJ & 0.5 & 0.5 & 1 & 0.1976 & \\
\hline Effectiveness & TG & KS & TJ & Weight & \multirow{4}{*}{$\begin{aligned} \lambda=3.0537 ; & R I=0.58 \\
C I=0.0269 ; & C R=0.0463\end{aligned}$} \\
\hline TG & 1 & 0.5 & 2 & 0.3119 & \\
\hline KS & 2 & 1 & 2 & 0.4905 & \\
\hline TJ & 0.5 & 0.5 & 1 & 0.1976 & \\
\hline \multicolumn{6}{|c|}{ Performance Index } \\
\hline Responsive time & TG & KS & TJ & Weight & \multirow{4}{*}{$\begin{array}{cl}\lambda=3.1 ; & R I=0.58 \\
C I=0.05 & C R=0.0862\end{array}$} \\
\hline TG & 1 & 3 & 0.3333 & 0.2864 & \\
\hline KS & 0.3333 & 1 & 0.3333 & 0.1399 & \\
\hline TJ & 3 & 3 & 1 & 0.5736 & \\
\hline Order quantities & TG & KS & TJ & Weight & \multirow{4}{*}{$\begin{aligned} \lambda & =3.0539 ; \mathrm{RI}=0.58 \\
\mathrm{CI} & =0.027 ; \mathrm{CR}=0.0465\end{aligned}$} \\
\hline TG & 1 & 3 & 3 & 0.5889 & \\
\hline KS & 0.3333 & 1 & 2 & 0.2519 & \\
\hline TJ & 0.3333 & 0.5 & 1 & 0.1593 & \\
\hline On-time delivery & TG & KS & TJ & Weight & \multirow{4}{*}{$\begin{aligned} \lambda=3.0387 ; & R I=0.58 \\
C I=0.0194 ; C R & =0.0334\end{aligned}$} \\
\hline TG & 1 & 3 & 0.3333 & 0.2605 & \\
\hline $\mathrm{KS}$ & 0.3333 & 1 & 0.2 & 0.1062 & \\
\hline TJ & 3 & 5 & 1 & 0.63333 & \\
\hline
\end{tabular}

Table 6. Pair-wise comparison matrix among alternatives for subcriteria under cost, workforces, and supply chain

Table 6 demonstrates pair-wise comparison results among alternatives for the subcriteria under environmental issues, customs, and performance index. In environmental issues, the results of sewage system, electroplating certification, and regulations are presented. CR values for these three subcriteria are less than 0.1 which indicate the consistency of the results. Moreover, TG 
outperforms the other two alternatives in sewage system and regulations while $\mathrm{TJ}$ outperforms the other two alternatives in electroplating certification. For the subcriteria under customs, the results of level of customs, bonded areas, and effectiveness are presented. CR values for these three subcriteria are less than 0.1 , which indicate the consistency of the results. Furthermore, TG outperforms the other two alternatives in level of customs and bonded areas while KS outperforms the other two alternatives in effectiveness. For the subcriteria under performance index, the results of responsive time, order quantities, and on-time delivery are presented. CR values for these three subcriteria are less than 0.1 , which indicate the consistency of the results. Moreover, TJ outperforms the other two alternatives in responsive time and on-time delivery while TG outperforms the other two alternatives in order quantities.

Based on the ranking of the subcriteria in Table 4 and the pair-wise comparison matrices in Tables 5 and 6, some insights can be drawn from the tables. In Table 4, TG outperforms the other two alternatives in seven of the top ten subcriteria while TJ and KS outperform the other two alternatives in two and one of the top ten subcriteria, respectively. In addition, TG encounters the highest weight in order quantities, minimum wages, supplier network, construction cost, labor force population, bonded areas, and regulations that are ranked $1,3,4,6,7,8$, and 10, respectively. TJ encounters the highest weight in on-time delivery and responsive time that are ranked 5 and 9, respectively. KS has obtained the highest weight only in land purchasing cost that is ranked second within the subcriteria. Insights in Tables 4-6 indicate that TG might be the best choice among the three alternatives since it outperforms the other two alternatives in most of the subcriteria. Although an initial insight indicates TG to be the best choice, the decision should be based on the total weight of the three alternatives. The total weighted results for decision are demonstrated in Table 7.

In Table 7, the total weights of TG, KS, and TJ are $0.4425,0.3248$, and 0.2327 , respectively. Hence, TG will be the best choice among the three alternatives. The result achieved by using AHP has been confirmed with high ranking managers in the company. A positive response from the managerial department calling for the same decision strengthens the values of this research. Although our results coincide with the company's decision, some insights are observed from the criteria and location characters. In the pairwise comparisons, TG outperforms the other two alternatives (KS and TJ) in 13 out of 18 criteria. This phenomenon indicates that TG is already favored by most of the interviewed employee. The reason might be that TG is the company's largest manufacturing base in China with better supply chain connections and workforce environment than the other two alternatives. Although land purchasing cost for TG is higher than the other two alternatives, construction cost is lower and rental opportunity is higher in TG. These advantages of TG contribute to the weight calculation in AHP and lead to the selection of TG. 


\begin{tabular}{|c|c|c|c|c|c|}
\hline \multirow{2}{*}{$\begin{array}{l}\text { Criterion } \\
\text { (weight) }\end{array}$} & \multicolumn{2}{|c|}{ Subcriteria and weight } & \multicolumn{3}{|c|}{ Alternative } \\
\hline & Subcriterion & Weight & TG & KS & $\mathbf{T J}$ \\
\hline \multirow{3}{*}{ Cost $(0.287)$} & Land purchasing cost & 0.6333 & 0.0833 & 0.7235 & 0.1932 \\
\hline & Construction cost & 0.2605 & 0.5889 & 0.2519 & 0.1593 \\
\hline & Rental opportunities & 0.1062 & 0.6479 & 0.1222 & 0.2299 \\
\hline \multirow{3}{*}{$\begin{array}{l}\text { Supply Chain } \\
\quad(0.127)\end{array}$} & Suppliers network & 0.6278 & 0.6333 & 0.2605 & 0.1062 \\
\hline & Logistics & 0.3129 & 0.4905 & 0.3119 & 0.1976 \\
\hline & Ports & 0.0594 & 0.5390 & 0.2973 & 0.1638 \\
\hline \multirow{3}{*}{$\begin{array}{c}\text { Workforces } \\
(0.197)\end{array}$} & Minimum wages & 0.6334 & 0.5390 & 0.2973 & 0.1638 \\
\hline & Labor force population & 0.2604 & 0.5390 & 0.1638 & 0.2973 \\
\hline & Social insurance & 0.1062 & 0.5889 & 0.2519 & 0.1593 \\
\hline \multirow{3}{*}{$\begin{array}{c}\text { Environment } \\
\text { al issues } \\
(0.055)\end{array}$} & Sewage system & 0.0738 & 0.5390 & 0.2973 & 0.1638 \\
\hline & Electroplating certification & 0.2828 & 0.2611 & 0.3278 & 0.4111 \\
\hline & Regulations & 0.6434 & 0.4905 & 0.1976 & 0.3119 \\
\hline \multirow{3}{*}{$\begin{array}{l}\text { Customs } \\
(0.034)\end{array}$} & Level of customs & 0.6434 & 0.5390 & 0.2973 & 0.1638 \\
\hline & Bonded areas & 0.2828 & 0.4905 & 0.3119 & 0.1976 \\
\hline & Effectiveness & 0.0738 & 0.3119 & 0.4905 & 0.1976 \\
\hline \multirow{3}{*}{$\begin{array}{l}\text { Performance } \\
\text { index }(0.3)\end{array}$} & Responsive time & 0.1062 & 0.2864 & 0.1399 & 0.5736 \\
\hline & Order quantities & 0.6333 & 0.5889 & 0.2519 & 0.1593 \\
\hline & On-time delivery & 0.2605 & 0.2605 & 0.1062 & 0.6333 \\
\hline \multicolumn{3}{|c|}{ Total weight of alternatives } & 0.4425 & 0.3248 & 0.2327 \\
\hline \multicolumn{3}{|c|}{ Rank } & 1 & 2 & 3 \\
\hline
\end{tabular}

Table 7. Rank of the alternatives

\subsection{Sensitivity Analysis}

According to Table 7, the orders of six criteria with the highest to lowest weights are performance index, cost, workforces, supply chain, environmental issues, and customs. Environmental issues and customs are together associated with only total weight of $8.9 \%$ that will not have significant impact on location selection. Based on the Pareto rule, environmental issues and customs will be removed from the criteria list. Therefore, the remaining four criteria will be applied to evaluate the alternatives using AHP.

\begin{tabular}{|c|c|c|c|c|c|}
\hline Criteria & Cost & Supply chain & Workforces & $\begin{array}{c}\text { Performance } \\
\text { index }\end{array}$ & Weight \\
\hline Cost & 1.00 & 3.00 & 2.00 & 1.00 & 0.3359 \\
\hline Supply chain & 0.33 & 1.00 & 0.33 & 0.33 & 0.0988 \\
\hline Workforces & 0.50 & 3.00 & 1.00 & 0.33 & 0.1898 \\
\hline Performance index & 1.00 & 3.00 & 3.00 & 1.00 & 0.3754
\end{tabular}

Table 8. Pair-wise comparison matrix for four criteria 
In Table 8, presenting the pair-wise comparison results for four criteria, performance index and cost own the highest weights. As $\lambda$ value is 4.1193 and RI value is $0.9, C I$ and $C R$ values are 0.0398 and 0.0442 , respectively. The $C R$ value is less than 0.1 , which indicates the consistency of the questionnaire results.

Table 9 demonstrates the results of pair-wise comparison matrix of subcriteria, all the CR values are less than 0.1 , indicating the consistency of the subcriteria. In each criterion, the weight of a specific subcriterion dominates the weights of the other two subcriteria. For instance, Land purchasing cost weighs 0.633 in cost while the other two subcriteria, i.e., construction cost and rental opportunities, only are of much smaller weights of 0.26 and 0.107 , respectively. Moreover, supplier network, minimum wages, and order quantities also dominate the other two subcriteria in supply chain, workforce, and performance index, respectively.

\begin{tabular}{|c|c|c|c|c|c|}
\hline Cost & $\begin{array}{l}\text { Land purchasing } \\
\text { cost }\end{array}$ & \multicolumn{2}{|c|}{ Construction cost } & $\begin{array}{c}\text { Rental } \\
\text { opportunities }\end{array}$ & Weight \\
\hline Land purchasing cost & 1.00 & & 3.00 & 5.00 & 0.6333 \\
\hline Construction cost & 0.333 & & 1.00 & 3.00 & 0.26 \\
\hline Rental opportunities & 0.2 & & 0.333 & 1.00 & 0.107 \\
\hline \multicolumn{6}{|c|}{$\lambda=3.0387 ; \mathrm{RI}=0.58 ; \mathrm{CI}=0.0194 ; \mathrm{CR}=0.0334$} \\
\hline Supply chain & Suppliers network & & Logistics & Ports & Weight \\
\hline Suppliers network & 1.0000 & & 3.0000 & 7.0000 & 0.6278 \\
\hline Logistics & 0.3330 & & 1.0000 & 7.0000 & 0.3129 \\
\hline Ports & 0.1111 & & 0.1429 & 1.0000 & 0.0594 \\
\hline \multicolumn{6}{|c|}{$\lambda=3.0271 ; \mathrm{RI}=0.58 ; \mathrm{CI}=0.0136 ; \mathrm{CR}=0.0234$} \\
\hline Workforces & Minimum wages & & $\begin{array}{l}\text { Labor force } \\
\text { population }\end{array}$ & Social insurance & Weight \\
\hline Minimum wages & 1.0 & 00 & 3.0000 & 5.0000 & 0.6334 \\
\hline Labor force population & 0.3 & 330 & 1.0000 & 3.0000 & 0.2604 \\
\hline Social insurance & 0.2 & 00 & 0.3333 & 1.0000 & 0.1062 \\
\hline \multicolumn{6}{|c|}{$\lambda=3.0384 ; \mathrm{RI}=0.58 ; \mathrm{CI}=0.0192 ; \mathrm{CR}=0.0331$} \\
\hline Performance index & Responsive time & & Order quantities & On-time delivery & Weight \\
\hline Responsive time & 1.0 & 00 & 0.2000 & 0.3333 & 0.1062 \\
\hline Order quantities & 5.0 & 00 & 1.0000 & 3.0000 & 0.6333 \\
\hline On-time delivery & 3.0 & 00 & 0.3333 & 1.0000 & 0.2605 \\
\hline \multicolumn{6}{|c|}{$\lambda=3.0387 ; \mathrm{RI}=0.58 ; \mathrm{CI}=0.0194 ; \mathrm{CR}=0.0334$} \\
\hline
\end{tabular}

Table 9. Pair-wise comparison matrix for the subcriteria of four selected criteria 


\begin{tabular}{|c|c|c|c|c|}
\hline \multirow{2}{*}{ Criterion (weight) } & \multicolumn{2}{|c|}{ Subcriteria and weights } & \multirow{2}{*}{ Total weight of subcriteria } & \multirow{2}{*}{ Rank } \\
\hline & Subcriteria & Weight & & \\
\hline \multirow{3}{*}{ Cost $(0.3359)$} & Land purchasing cost & 0.633 & 0.2128 & 2 \\
\hline & Construction cost & 0.260 & 0.0875 & 5 \\
\hline & Rental opportunities & 0.106 & 0.0357 & 9 \\
\hline \multirow{3}{*}{ Supply Chain (0.0988) } & Supplier network & 0.6278 & 0.0620 & 6 \\
\hline & Logistics & 0.3129 & 0.0309 & 10 \\
\hline & Ports & 0.0594 & 0.0059 & \\
\hline \multirow{3}{*}{ Workforces (0.1898) } & Minimum wages & 0.633 & 0.1202 & 3 \\
\hline & Labor force population & 0.260 & 0.0494 & 7 \\
\hline & Social insurance & 0.106 & 0.0202 & \\
\hline \multirow{3}{*}{$\begin{array}{l}\text { Performance index } \\
\quad(0.3754)\end{array}$} & Responsive time & 0.106 & 0.0399 & 8 \\
\hline & Order quantities & 0.633 & 0.2378 & 1 \\
\hline & On-time delivery & 0.260 & 0.0978 & 4 \\
\hline
\end{tabular}

Table 10. Ranking of the subcriteria for four criteria

Table 10 shows the results of the ranking of the subcriterions. Order quantities in performance index criterion have the highest weight among subcriteria. The weights of all three subcriteria in performance index criterion are ranked in the top ten and two subcriteria (i.e., order quantities and on-time delivery) are also ranked in the top five. The subcriterion with the second highest weight is land purchasing cost under the cost criterion while the third and fourth highest weights are minimum wages and on-time delivery in workforce and performance index, respectively. 


\begin{tabular}{|c|c|c|c|c|c|}
\hline \multicolumn{6}{|c|}{ Cost } \\
\hline Land purchasing cost & TG & KS & T] & Weight & \multirow{4}{*}{$\begin{array}{c}\lambda=3.0658 ; \mathrm{RI}=0.58 \\
\mathrm{CI}=0.0329 ; \mathrm{CR}=0.0567\end{array}$} \\
\hline TG & 1 & 0.1429 & 0.3333 & 0.0833 & \\
\hline KS & 7 & 1 & 5 & 0.7235 & \\
\hline $\mathrm{TJ}$ & 3 & 0.2 & 1 & 0.1932 & \\
\hline Construction cost & TG & KS & TJ & Weight & \multirow{4}{*}{$\begin{aligned} \lambda & =3.0539 ; \mathrm{RI}=0.58 \\
\mathrm{CI} & =0.027 ; \mathrm{CR}=0.0465\end{aligned}$} \\
\hline TG & 1 & 3 & 3 & 0.5889 & \\
\hline KS & 0.3333 & 1 & 2 & 0.2519 & \\
\hline $\mathrm{TJ}$ & 0.3333 & 0.5 & 1 & 0.1593 & \\
\hline Rental opportunities & TG & KS & $\mathrm{TJ}$ & Weight & \multirow{4}{*}{$\begin{array}{c}\lambda=3.0037 ; \mathrm{RI}=0.58 \\
\mathrm{CI}=0.0018 ; \mathrm{CR}=0.0032\end{array}$} \\
\hline TG & 1 & 5 & 3 & 0.6479 & \\
\hline KS & 0.2 & 1 & 0.5 & 0.1222 & \\
\hline $\mathrm{TJ}$ & 0.3333 & 2 & 1 & 0.2299 & \\
\hline \multicolumn{6}{|c|}{ Workforces } \\
\hline Labor force population & TG & KS & T] & Weight & \multirow{4}{*}{ 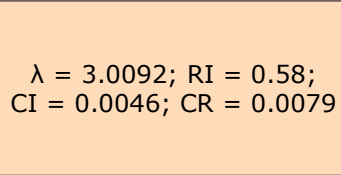 } \\
\hline TG & 1 & 3 & 2 & 0.539 & \\
\hline KS & 0.3333 & 1 & 0.5 & 0.1638 & \\
\hline $\mathrm{TJ}$ & 0.5 & 2 & 1 & 0.2973 & \\
\hline Minimum wages & TG & KS & TJ & Weight & \multirow{4}{*}{$\begin{array}{c}\lambda=3.0092 ; \mathrm{RI}=0.58 \\
\mathrm{CI}=0.0046 ; \mathrm{CR}=0.0079\end{array}$} \\
\hline TG & 1 & 2 & 3 & 0.539 & \\
\hline KS & 0.5 & 1 & 2 & 0.2973 & \\
\hline $\mathrm{TJ}$ & 0.3333 & 0.5 & 1 & 0.1638 & \\
\hline Social insurance & TG & KS & TJ & Weight & \multirow{4}{*}{$\begin{array}{l}\lambda=3.0539 ; \quad R I=0.58 \\
C I=0.027 ; C R=0465\end{array}$} \\
\hline TG & 1 & 3 & 3 & 0.5889 & \\
\hline KS & 0.3333 & 1 & 2 & 0.2519 & \\
\hline TJ & 0.3333 & 0.5 & 1 & 0.1593 & \\
\hline \multicolumn{6}{|c|}{ Supply Chain } \\
\hline Supplier network & TG & $\mathrm{KS}$ & TJ & Weight & \multirow{4}{*}{$\begin{aligned} \lambda=3.0387 ; & R I=0.58 \\
C I=0.0194 ; C R & =0.0334\end{aligned}$} \\
\hline TG & 1 & 3 & 5 & 0.6333 & \\
\hline KS & 0.3333 & 1 & 3 & 0.2605 & \\
\hline TJ & 0.2 & 0.3333 & 1 & 0.1062 & \\
\hline Logistics & TG & KS & TJ & Weight & \multirow{4}{*}{$\begin{array}{c}\lambda=3.0537 ; \mathrm{RI}=0.58 \\
\mathrm{CI}=0.0269 ; \mathrm{CR}=0.0463\end{array}$} \\
\hline TG & 1 & 2 & 2 & 0.4905 & \\
\hline KS & 0.5 & 1 & 2 & 0.3119 & \\
\hline TJ & 0.5 & 0.5 & 1 & 0.1976 & \\
\hline Ports & TG & KS & TJ & Weight & \multirow{4}{*}{$\begin{aligned} \lambda=3.0092 ; & R I=0.58 \\
C I=0.0046 ; & C R=0.0079\end{aligned}$} \\
\hline TG & 1 & 2 & 3 & 0.539 & \\
\hline KS & 0.5 & 1 & 2 & 0.2973 & \\
\hline $\mathrm{TJ}$ & 0.3333 & 0.5 & 1 & 0.1638 & \\
\hline \multicolumn{6}{|c|}{ Performance Index } \\
\hline Responsive time & TG & KS & TJ & Weight & \multirow{4}{*}{$\begin{array}{c}\lambda=3.1 ; \mathrm{RI}=0.58 \\
\mathrm{CI}=0.05 ; \mathrm{CR}=0.0862\end{array}$} \\
\hline TG & 1 & 3 & 0.3333 & 0.2864 & \\
\hline KS & 0.3333 & 1 & 0.3333 & 0.1399 & \\
\hline $\mathrm{TJ}$ & 3 & 3 & 1 & 0.5736 & \\
\hline Order quantities & TG & $\mathrm{KS}$ & TJ & Weight & \multirow{4}{*}{$\begin{aligned} \lambda & =3.0539 ; R I=0.58 \\
C I & =0.027 ; C R=0.0465\end{aligned}$} \\
\hline TG & 1 & 3 & 3 & 0.5889 & \\
\hline KS & 0.3333 & 1 & 2 & 0.2519 & \\
\hline $\mathrm{TJ}$ & 0.3333 & 0.5 & 1 & 0.1593 & \\
\hline On-time delivery & TG & KS & TJ & Weight & \multirow{4}{*}{$\begin{aligned} \lambda=3.0387 ; & R I=0.58 \\
C I=0.0194 ; C R & =0.0334\end{aligned}$} \\
\hline TG & 1 & 3 & 0.3333 & 0.2605 & \\
\hline KS & 0.3333 & 1 & 0.2 & 0.1062 & \\
\hline TJ & 3 & 5 & 1 & 0.63333 & \\
\hline
\end{tabular}

Table 11. Pair-wise comparison matrix among alternatives for subcriteria under cost

Table 11 shows the pair-wise comparison results among alternatives for twelve subcriteria. In Table 11, results of land purchasing cost, construction cost, and rental opportunities are listed. 
CR values for these three subcriteria are less than 0.1 , which indicate the consistency of the results. Furthermore, TG outperforms the other two alternatives in construction cost and rental opportunities while KS outperforms the other two alternatives in land purchasing cost. For the subcriteria under workforces, results of labor force population, minimum wages, and social insurance are presented in Table 11. CR values for these three subcriteria are less than 0.1, which indicates the consistency of the results. Also, TG outperforms the other two alternatives in all three subcriteria. For the subcriteria under supply chain, results of supplier network, logistics, and ports are presented. CR values for these three subcriteria are again less than 0.1 , which indicate the consistency of the results. Also, TG outperforms the other two alternatives in all three subcriteria. In Table 11, results of responsive time, order quantities, and on-time delivery are presented. CR values for these three subcriteria are less than 0.1 , which indicate the consistency of the results. Moreover, TJ outperforms the other two alternatives in responsive time and on-time delivery while TG outperforms the other two alternatives in order quantities.

Based on the results of ranking the subcriteria in Table 10 and the pair-wise comparison matrices in Table 11, TG outperforms the other two alternatives in seven of the top ten ranked subcriteria while TJ and KS outperform the other two alternatives in two and one of the top ten subcriteria, respectively. Moreover, TG has the highest weight in order quantities, minimum wages, construction cost, suppliers network, labor force population, rental opportunities, and logistics that are ranked $1,3,5,6,7,9$, and 10, respectively. TJ encounters the highest weight in on-time delivery and responsive time, ranked 4 and 8 , respectively. KS secures the highest weight only in land purchasing cost which is ranked 2 within the subcriteria. The total weighted results for decision are demonstrated in Table 12.

\begin{tabular}{|c|c|c|c|c|c|}
\hline \multirow{2}{*}{ Criteria } & \multicolumn{2}{|c|}{ Subcriteria and weights } & \multicolumn{3}{|c|}{ Alternatives } \\
\hline & Subcriteria & Weight & TG & KS & $\mathbf{T}$ \\
\hline \multirow{3}{*}{ Cost $(0.3359)$} & Land purchasing cost & 0.6333 & 0.0833 & 0.7235 & 0.1932 \\
\hline & Construction cost & 0.2605 & 0.5889 & 0.2519 & 0.1593 \\
\hline & Rental opportunities & 0.1062 & 0.6479 & 0.1222 & 0.2299 \\
\hline \multirow{3}{*}{$\begin{array}{l}\text { Supply Chain } \\
(0.0988)\end{array}$} & Supplier network & 0.6278 & 0.6333 & 0.2605 & 0.1062 \\
\hline & Logistics & 0.3129 & 0.4905 & 0.3119 & 0.1976 \\
\hline & Ports & 0.0594 & 0.5390 & 0.2973 & 0.1638 \\
\hline \multirow{3}{*}{$\begin{array}{c}\text { Workforces } \\
(0.1898)\end{array}$} & Minimum wages & 0.6334 & 0.5390 & 0.2973 & 0.1638 \\
\hline & Labor force population & 0.2604 & 0.5390 & 0.1638 & 0.2973 \\
\hline & Social insurance & 0.1062 & 0.5889 & 0.2519 & 0.1593 \\
\hline \multirow{3}{*}{$\begin{array}{c}\text { Performance } \\
\text { index }(0.3754)\end{array}$} & Responsive time & 0.1062 & 0.2864 & 0.1399 & 0.5736 \\
\hline & Order quantities & 0.6333 & 0.5889 & 0.2519 & 0.1593 \\
\hline & On-time delivery & 0.2605 & 0.2605 & 0.1062 & 0.6333 \\
\hline \multicolumn{3}{|c|}{ Total weight of alternatives } & 0.4302 & 0.3327 & 0.2371 \\
\hline \multicolumn{3}{|c|}{ Rank } & 1 & 2 & 3 \\
\hline
\end{tabular}

Table 12. The ranking of the alternatives for four criteria 
In Table 12, the total weights of TG, KS, and TJ are $0.4302,0.3327$, and 0.2371 , respectively. Hence, TG will be the best choice among these three alternatives. Comparing the results in Tables 7 and 12, TG is the best alternative in both six and four criteria. The phenomenon could be resulted from the significant differences of weight among criteria. To realize the accuracy of the result achieved in the research and the impact level of criteria, findings have been discussed with the company's high ranking managers. They confirmed the accuracy of the result and responded well to the reasons and levels of the criteria. Table 13 shows the managers' responses.

\begin{tabular}{|c|l|l|}
\hline Criteria & Sensitivity & Managers' responses \\
\hline Performance index & High & $\begin{array}{l}\text { The studied company is an OEM (Original Equipment Manufacturer) } \\
\text { company and customer's satisfactions are the most important } \\
\text { concern for this company. Therefore, fulfilling the performance } \\
\text { index is the main concern for constructing a new plant. }\end{array}$ \\
\hline Workforces & High & $\begin{array}{l}\text { Constructing a new plant will have larger initial investment and } \\
\text { reducing cost is always an important consideration for a company } \\
\text { especially for its fiscal department. }\end{array}$ \\
\hline Supply Chain & Medium & $\begin{array}{l}\text { The labor shortage in these years had caused the delay of the } \\
\text { orders. A stable workforces will enhance a company's fulfillment of } \\
\text { on-time delivery and responsive time and will improve customer } \\
\text { satisfaction. }\end{array}$ \\
\hline Environmental issues & Low & $\begin{array}{l}\text { In 3C manufacturing industries, hub warehouse is usually applied } \\
\text { to avoid material or component shortage that reduces the impact } \\
\text { of a poor supplier network. However, the logistics and distances to } \\
\text { ports will affect hub inventory replenishment and order delivery. } \\
\text { Therefore, the impact of supply chain on decision is at medium } \\
\text { level. }\end{array}$ \\
\hline Customs & $\begin{array}{l}\text { The studied company has electroplating certification in all three } \\
\text { alternatives and there is no difference in the environmental issues } \\
\text { in these three alternatives. }\end{array}$ \\
\hline & $\begin{array}{l}\text { The bonded areas have been implemented in all three locations for } \\
\text { years and customs offices in these locations have always } \\
\text { cooperated with industries to hasten the process. Therefore, the } \\
\text { effect of customs is low. }\end{array}$ \\
\hline
\end{tabular}

Table 13. Sensitivities of the criteria

In Table 13, three criteria, performance index, cost, and workforces, are highlighted for high level of sensitivity. The reason for performance index to have such high sensitivity is that fulfilling customers' requirements is always the primal concern for an OEM company. Cost and Workforces are categorized to have high sensitivity since fiscal budget and stable workforces are also important factors of a company's long-term plan. Supply chain only has medium sensitivity because many strategies such as hub, supply chain integration, and strategic alliance are implemented for years to reduce the bullwhip effect and inventory. The influences of supply chain fall on the global logistics integration. Furthermore, environmental issues and customs are categorized with low sensitivity level. The reason is that both criteria have been operated for years and environmental requirements and customs office cooperation are so well constructed that reduce impact on location selection. 


\subsection{Implementation of the Concept}

To implement the proposed framework in practice, a process flow of location selection is demonstrated using Figure 2. In Figure 2, a decision making board will be formed to review the criteria and final results of AHP once the location selection is acquired. The board will determine whether the criteria should be renewed or be constructed. If the criteria have to be renewed or be constructed, the board will obtain criteria using Delphi method. Once the criteria are constructed, results will be achieved using AHP and presented to the decision making board for final decision.

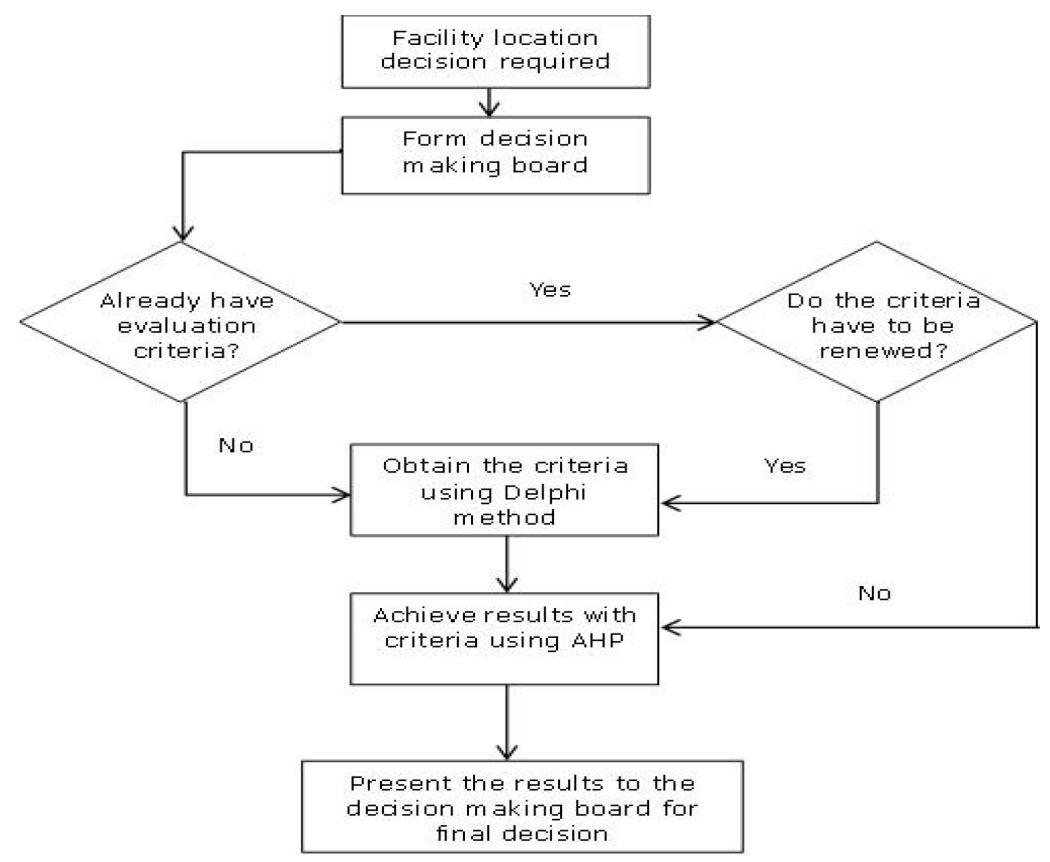

Figure 2. Process flow in location selection

\section{Conclusion and Future Research}

In this research, AHP has been implemented for optimizing location selection. The questionnaires have been conducted in a $3 \mathrm{C}$ manufacturing company to identify the criteria and subcriteria. Pair-wise comparisons have also been conducted for AHP analysis. The results show that the best location, identified using AHP, meets well with the company's final decision and primal production base. Sensitivity analysis has also been performed to realize the sensitivity level of criteria. Our results and responses from the company's high rank managers demonstrate that performance index, cost, and workforces are the most important concerns in location selection. In contrast, environmental issues and customs have a minor impact on plant location decision. Although AHP has proved to be successful in location decision for real cases, some directions can be investigated to further improve the developed framework. More specifically, including additional criteria and new locations other than existing production bases can be inserted into the framework to provide a more general analysis. 


\section{References}

Amiri, M.P. (2010). Project selection for oil-fields development by using the AHP and fuzzy TOPSIS methods. Expert Systems with Applications, 37, 6218-6224. http://dx.doi.org/10.1016/j.eswa.2010.02.103

Arbabani, A.B., \& Farahani, R.Z. (2012). Facility location dynamics: An overview of classifications and applications. Computers \& Industrial Engineering, 62, 408-420. http://dx.doi.org/10.1016/j.cie.2011.09.018

Balinski, M.L. (1965). Integer Programming: Methods, Uses, Computation. Management Science, 12, 253-313. http://dx.doi.org/10.1287/mnsc.12.3.253

Büyüközkan, G., Çifçi, G., \& Güleryüz, S. (2011). Strategic analysis of healthcare service quality using fuzzy AHP methodology. Expert Systems with Applications, 38, 9407-424. http://dx.doi.org/10.1016/j.eswa.2011.01.103

Calabrese, A., Costa, R., \& Menichini, T. (2013). Using fuzzy AHP to manage intellectual capital assets: An application to the ICT service industry. Expert Systems with Applications, 40, 3747-3755. http://dx.doi.org/10.1016/j.eswa.2012.12.081

Canbolat, M.S., \& von Massow, M. (2011). Location emergency facilities with random demand for risk minimization. Expert Systems with Applications, 38, 10099-10106. http://dx.doi.org/10.1016/j.eswa.2011.02.001

Chen, M.K., \& Wang, S.-C. (2010). The critical factors of success for information service industry in developing international market: Using analytic hierarchy process (AHP) approach. Expert Systems with Applications, 37, 694-704. http://dx.doi.org/10.1016/j.eswa.2009.06.012

Choudhary, D. \& Shankar, R. (2012). A Steep-fuzzy AHP-TOPSIS framework for evaluation and selection of thermal power plant location: A case study from India. Energy, 42, 510-521. http://dx.doi.org/10.1016/j.energy.2012.03.010

Church, R.L., \& Revelle, C.S. (1976). Theoretical and Computational Links Between The p-median Location Set-Covering and the Maximal Covering Location Problem. Geographical Analysis, 8, 406-415. http://dx.doi.org/10.1111/j.1538-4632.1976.tb00547.x

Dagdeviren, M., Yavuz, S., \& Kilinc, N. (2009). Weapon selection using the AHP and TOPSIS methods under fuzzy environment. Expert Systems with Applications, 36, 8143-8151. http://dx.doi.org/10.1016/j.eswa.2008.10.016

Farahani, R.Z., SteadieSeifi, M., \& Asgari, N. (2010). Multiple criteria facility location problems: A survey. Applied Mathematical Modelling, 34, 1689-1709. http://dx.doi.org/10.1016/j.apm.2009.10.005 
Gaudenzi, B., \& Borghesi, A. (2006). Managing risks in the supply chain using the AHP method. International Journal of Logistics Management, 17(1), 114-136. http://dx.doi.org/10.1108/09574090610663464

Gulpinar, N., Pachamanova, D., \& Canakoglu, E. (2013). Robust strategies for facility location under uncertainty. European Journal of Operational Research, 225, 21-35. http://dx.doi.org/10.1016/j.ejor.2012.08.004

Hahn, E.D., \& Bunyaratavej, K. (2010). Services cultural alignment in offshoring: The impact of cultural dimensions on offshoring location choices. Journal of Operations Management, 28, 186-193. http://dx.doi.org/10.1016/j.jom.2009.10.005

Handley, S.M., \& Benton Jr., W.C. (2013). The influence of task-and location-specific complexity on the control and coordination costs in global outsourcing relationships. Journal of Operations Management, 31, 109-128. http://dx.doi.org/10.1016/j.jom.2012.12.003

Ho, W., He, T., Lee, C.K.M., \& Emourznejad, A. (2012). Strategic logistics outsourcing: An integrated QFD and fuzzy AHP approach. Expert Systems with Applications, 39, 10841-10850. http://dx.doi.org/10.1016/j.eswa.2012.03.009

Hong, L., \& Xiaohua, Z. (2011). Study on location selection of multi-objective emergency logistics center based on AHP. Procedia Engineering, 15, 2128-2132. http://dx.doi.org/10.1016/j.proeng.2011.08.398

Huff, D.L. (1966). A Programmed Solution for approximating an optimum retail location. Land Economics, 42, 293-303. http://dx.doi.org/10.2307/3145346

Ishizaka, A., \& Labib, A. (2011). Review of the main developments in the analytic hierarchy process. Expert Systems with Applications, 38, 14336-14345. http://dx.doi.org/10.1016/j.eswa.2011.04.143

Jaques, N., \& Morgan, C. (2004). Adapting the Analytical Hierarchy Process to identify inventory risk. International Journal of Logistics Management, 15(2), 93-105. http://dx.doi.org/10.1108/95740930480000354

Jung, H. (2011). A fuzzy AHP-GP approach for integrated production-planning considering manufacturing partners. Expert Systems with Applications, 38, 5833-5840. http://dx.doi.org/10.1016/j.eswa.2010.11.039

Kuo, R.J., Chi, S.C., \& Kao, S.S. (2002). A decision support system for selecting convenience store location through integration of fuzzy AHP and artificial neural network. Computers in Industry, 47, 199-214. http://dx.doi.org/10.1016/S0166-3615(01)00147-6 
Lee, J.M., \& Lee, Y.H. (2012). Facility location and scale decision problem with customer preference. Computers \& Industrial Engineering, 63, 184-191. http://dx.doi.org/10.1016/j.cie.2012.02.005

Lee, S., Kim, W., Kim, Y.M., \& Oh, K.J. (2012). Using AHP to determine intangible priority factors for technology transfer adoption. Expert Systems with Applications, 39, 6388-6395. http://dx.doi.org/10.1016/j.eswa.2011.12.030

Marin, A. (2011). The discrete facility location problem with balanced allocation of customers. European Journal of Operational Research, 210, 27-38. http://dx.doi.org/10.1016/j.ejor.2010.10.012

McDermott, C.M., \& Stock, G.N. (2011). Focus as emphasis: Conceptual and performance implications for hospitals. Journal of Operations Management, 29, 616-626. http://dx.doi.org/10.1016/j.jom.2011.02.002

Nozick, L.K., \& Turnquist, M.A. (2001). Inventory, Transportation, Service Quality and the Location of Distribution Centers. European Journal of Operational Research, 129, 362-371. http://dx.doi.org/10.1016/S0377-2217(00)00234-4

Ounnar, F., \& Pujo, P. (2005). Evaluating suppliers within a self-organized logistical network. International Journal of Logistics Management, 16(1), 159-172. http://dx.doi.org/10.1108/09574090510617402

Partovi, R. (2006). An analytic model for locating facilities strategically. Omega, 34, 41-55. http://dx.doi.org/10.1016/j.omega.2004.07.018

Rad, A., Naderi, B., \& Soltani, M., 2011. Clustering and ranking university majors using data mining and AHP algorithms: A case study in Iran. Expert Systems with Applications, 38, 755-763. http://dx.doi.org/10.1016/j.eswa.2010.07.029

Randhawa, S.U., \& West, T.M. (1995). An Integrated Approach to Facility Location Problems. $17^{\text {th }}$ International Conference on Computers and Industrial Engineering, 29(1-4), 261-265. http://dx.doi.org/10.1016/0360-8352(95)00082-C

Saaty, TL. (1980). The analytic hierarchy process. New York, USA: McGraw Hill.

Saaty, TL. (1990). How to mark a decision: the analytic hierarchy process. European Journal of Operational Research, 48, 9-26. http://dx.doi.org/10.1016/0377-2217(90)90057-I

Sánchez-Lozano, J.M., García-Cascales, M.S., \& Lamata, M.T. (2015). Evaluation of suitable locations for the installation of solar thermoelectric power plant. Computers \& Industrial Engineering, 87, 343-355. http://dx.doi.org/10.1016/j.cie.2015.05.028 
Tzeng, G.H., Teng, M.H., Chen, J.J., \& Opricovic, S. (2002). Multicriteria selection for a restaurant location in Taipei. Hospitality Management, 21, 171-187. http://dx.doi.org/10.1016/S0278-4319(02)00005-1

Vahidnia, M.H., Alesheikh, A.A., \& Alimohammadi, A. (2009). Hospital site selection using fuzzy AHP and its derivatives. Journal of Environmental Management, 90, 3048-3056. http://dx.doi.org/10.1016/j.jenvman.2009.04.010

Vidal, L.-A., Sahin, E., Martelli, N., Berhoune, M., \& Bonan, B. (2010). Applying AHP to select drugs to be produced by anticipation in a chemotherapy compounding unit. Expert Systems with Applications, 37, 1528-1534. http://dx.doi.org/10.1016/j.eswa.2009.06.067

Vidal, L.-A., Marie, F., \& Bocquet, J.-C. (2011). Using a Delphi process and the Analytic Hierarchy Process (AHP) to evaluate the complexity of projects. Expert Systems with Applications, 38, 5388-5405. http://dx.doi.org/10.1016/j.eswa.2010.10.016

Wu, C.R., Lin, C.T., \& Chen, H.C. (2007). Optimal selection of location for Taiwanese hospitals to ensure a competitive advantage by using the analytic hierarchy process and sensitivity analysis. Building and Environment, 42, 1431-1444. http://dx.doi.org/10.1016/j.buildenv.2005.12.016

Zhang, Y., Deng, X., Wei, D., \& Deng, Y. (2012). Assessment of E-Commerce security using AHP and evidential reasoning. Expert Systems with Applications, 39, 3611-3623. http://dx.doi.org/10.1016/j.eswa.2011.09.051

Journal of Industrial Engineering and Management, 2015 (www.jiem.org)

Article's contents are provided on an Attribution-Non Commercial 3.0 Creative commons license. Readers are allowed to copy, distribute and communicate article's contents, provided the author's and Journal of Industrial Engineering and Management's names are included. It must not be used for commercial purposes. To see the complete license contents, please visit http://creativecommons.org/licenses/by-nc/3.0/. 